\title{
ARE EMPIRES STRIKING BACK? \\ A POLITICAL AND CULTURAL COMPARISON OF THE EUROPEAN UNION AND RUSSIA.
}

\author{
Jérôme Dumetz
}

Plekhanov Russian Economic University, Russia, Unicorn College, Czech Republic, jerome.dumetz@clamart.net

\begin{abstract}
The article is a position paper focusing on the current standoff between two regional powers, the European Union and Russia. Following a series of crises, in particular the annexation of Crimea by the Russian Federation in 2014, the relationship between Russia and many of its neighbours has significantly deteriorated. This shift has led to various geopolitical opinions, often opposite and seemingly irreconcilable. A holistic and historical approach to this new reality leads some to question the validity of the current world order through the prism of the anachronistic concept of Empires. Subsequent to a review of definitions, the author analyses historical characteristics and political factors of the two territories on focus: the European Union and Russia. There are two outcomes of this study: On the one side, the European Union has become an organisation that shares many characteristics of an Empire, but several key elements exclude it from this political construction. On the other side, the geopolitical actions of Russia have shaped the position of the country into a structure that bears many of the artefacts of an Empire with key essential features. The conclusion of this argument states that the European Union is not an Empire by design, despite many resembling features; whilst Russia lives in an anachronistic paradigm of an Empire, without having the means of being one.
\end{abstract}

Keywords: Empires; Russia; European Union

Type of the paper: Position paper

JEL Classification: F5

\section{Introduction}

The European Union is an economic and a political entity inhabited by more than 500 millions citizens, living in 28 independent yet interrelated countries. In a little more than 50 years, the group of countries have integrated in various domains, beyond free trade. Many opponents of this construction, from various political backgrounds, often vilify the European integration of their nation as a loss of sovereignty and do not hesitate to epitomise the association as a new form of imperialism.

On the Eastern flank of the European Union, the Russian Federation has recently launched a series of actions that reminds some observers of the USSR. From massive military parades to frequent flights of nuclear bombers near the borders of neighbouring countries, a tempting parallel could be drawn between Russia's new attitude and that of the USSR. The paradigm sustaining this parallel is based on the return of Imperial politics.

The aim of this argument is to analyse the elements at stake in order to shed light on possible consequences of the current situation. Is the European continent confronted again by a 'Great Game', in which Empires challenge each other? We shall analyse the historical and political factors characterising each entity: The European Union and Russia. The findings of this article are that an Empire as a political construction has all but disappeared; only the European Union may now be associated with such a structure, and often by its opponents, but lacks the design to be so. Russia, following the fall of the Soviet Union, has become a Nation-state without the means to reclaim the title of Empire. 


\section{The Beginning of the End}

The end of the First World War and the Versailles treaty are often considered the beginning of the end for the Empires in Europe. Whilst the war started in the Balkans following the retreat of the Ottoman Empire, its conclusion saw the disappearance of the central Austrian-Hungarian Empire. On the eastern side of the continent, the Tsarist Russian Empire disappeared with the abdication of Nicholas II in February 1917. The two remaining European Empires, France and the United Kingdom, would see their decline a generation later, after the Second World War (Conte, 1992).

An Empire ('an aggregate of nations or people' according to the Webster dictionary) is a political organisation centred around one figure (an Emperor or Empress), but without cultural, linguistic or religious homogeneity (Kerr, 1922). Unlike a King, an Emperor could govern very different groups of people without having to harmonise his/her realm. Wars would lead to treaties and new wars to new treaties, shifting territorial control from one court to another. Beyond the governing elites of territories, the daily lives of the residents and commoners went mostly unchanged over time. The rise of Empires had allowed economic and cultural developments of entire regions without the extremism of nationalism. Whilst the language of the Empire's capital was often imposed in administrative acts, local dialects were not only tolerated but also enjoyed as part of a meshing amongst the population that would be hard to imagine today (Fabry, 2015).

Once Empires disappeared, populations defined their identities with new criteria, filling the void of the Empire. Following precedents such as the creation of France after its 1789 Revolution, many countries became nation-states unified around a common language and occasionally a unique religion. Often, the lives of minorities became precarious. In an apparent paradox, the dominant cultures of Empires were often minorities numerically, hence, forcing a constant balance of power in the governed lands. By the end of the 19th century, the ethnic Germans and the Hungarians represented only $24 \%$ and 20\%, respectively, of the inhabitants of the Austrian-Hungarian Empire (Redlich, 1929). In the Ottoman Empire, many Grand Viziers were from Albania. Once the Empires fell out of fashion, newly created nation-states often saw dominant cultures as synonymous with the majority of the population. For instance, $80 \%$ of the Austrian population belongs to the Austria cultural group, the Turkish majority represent $90 \%$ of the inhabitants of Turkey, and Hungary has become one of the most homogeneous countries in Europe with near $98 \%$ of its population claiming to be Hungarian. Some minorities in hard-to-access areas managed to keep their specificities, but many others were either forced to assimilate to the dominant culture or move out of the country (Shapovalova, 2016). The forced movement of large numbers of people became a landmark of the 20th century in Europe (Marrus, 1985).

\section{A New Type of Empire? The European Union}

The post-war era has seen the emergence of the European Union as a substitute for the Empire (Langer, 1962). Many opponents to the European Union construction see this creation as a loss of soveinty and assimilate such imperialist development as negative (Front National, 2016). Contrary to traditional Empires, however, membership in this Union is based on values and, most importantly, is voluntary (Harari, 2014). With its Parliament, its Commission, its Court of Justice and its bureaucratic operation and culture, it has all of the artefacts of the structure of an Empire. The European Union not only tolerates minority languages, but it actively promotes multi-linguism by translating mountains of documents every day as well as through its popular student exchange program, Erasmus (European Region Action Scheme for the Mobility of University Students). It goes without saying that its leadership is elected. Every 5 years, the Parliament members are elected by universal suffrage; member countries nominate all non-elected officials, often following a public hearing. The European Commission, similar to European Union's Cabinet Government, is composed of 28 members, each appointed by their country of origin. The whole commission is approved by the Parliament and the President of the Commission (currently Jean-Claude Junker from Luxembourg) is chosen from the political party at the Parliament, which secured the majority of the votes. More than once, 'commissioners' proposed by member countries have been publically rejected by the Parliament. Finally, the European civil servants (bureaucrats) amount to a small number, a bit more than 50,000. 
This is about the same number of civil servants employed by the city of Paris, a city of $2 \mathrm{M}$ when the European Unions counts more than 500M inhabitants. The recruitment is public, following solid screening and testing. Quotas ensure that all countries are represented. The increasingly powerful Court of Justice ensures that the rule of law, rather than nepotism, is the foundation of the organisation. European treaties trump any national regulation, hence creating a meta-culture with power over sovereign states.

Of course, not everyone in Europe is happy with this situation. Many voters support political parties that are vocal against what they feel is the abandonment of key sovereign artefacts such as laws, customs or currencies. The so-called 'Euro-sceptic' parties comprise up to $100 \mathrm{MPs}$ in the 751-strong European Parliament. Not surprisingly, the United Kingdom feels most uncomfortable with the organisation and has carefully opted-out of many harmonised processes such as the Schengen borderfree treaty or the Maastricht's creation of a single currency, the Euro. A planned referendum in 2016 in the country is meant to clarify what sort of political structure the British wish to live in: a sovereign 'United Kingdom' which resembles a small Empire or a 'simple' member in a 500-million Economic Empire, the European Union? (BBC, 2016)

\section{Russia, the Fallen Empire}

Russia followed a different path. It actually ceased to be an Empire in for a short period of time beginning in 1917. In October 1917, the Lenin-led Bolsheviks arrested Kerensky, the head of the provisional government, and rapidly signed the Brest-Litovsk peace treaty with Germany, hence sacrificing many of Russia's lands. The Bolsheviks lost the Baltic countries and recognised the independence of Ukraine. Countries such as Belarus and Ukraine enjoyed brief autonomy from the Russians before joining the newly created USSR in 1922. Following the 1941 invasions and war victories, the USSR governed 15 republics by 1945, with a population as diverse as Chukchi 'Eskimos' in the extreme north-east near the Bering Strait, Kirghiz mountaineers and Estonian office workers. The USSR, willing to differentiate itself from the Tsarist system, was careful not to appear as a new Russian empire, hence creating a new Soviet culture (Carrère d'Encausse, 1992). Whilst Russian was still used as the governing language and lingua franca amongst the population, local languages were not only tolerated but also promoted. Many talented linguists were sent across the territories to record, structure and ultimately save local languages (Pavlenko, 2014).

The fall of the USSR followed the same steps as the fall of other Empires. Owing to ever-increasing expenses at the fringe of the Empire to stabilise its borders and maintain loyalty to the central government, the dominant population suffered whilst the administrated lands were treated comparatively well as to prevent them from considering independence. For jobs of equal position, salaries in Soviet Russia were notoriously lower than those in other republics. Medical treatments were also of a much higher quality in satellite countries of Eastern Europe than in the USSR itself. For instance, life expectancy in Russia in the 1960s and 1970s (a period of peace) was two years less than that in Estonia and 4 years less than that in the Czech republic (World bank, 2016). When the Baltic countries declared independence in the summer of 1991, followed by other republics including Boris Yelstin's Russia, the Empire ended. In December 1991, Mikhail Gorbachev, the President of a now extinct Soviet Union, resigned (Dumetz, 2014).

Besides the renewal of former USSR-controlled countries' independence, these 15 new countries also enjoyed the rediscovery of their own cultures and languages. In most of these countries, Russian became at best a second language, mostly a third one. Today, some $94.1 \%$ of all EU-28 students at high-school level are studying English as a foreign language compared with less than one-fourth (23.0 \%) studying French, whilst less than one-fifth were studying Spanish (19.1\%) or German (18.9 \%). English is studied by $69-82 \%$ in Romania, Estonia, Latvia, the Czech Republic, Lithuania, Bulgaria and Slovakia, rising to more than $90 \%$ in Poland showing a clear shift in countries where Russian was a compulsory foreign language during most of the Soviet era. Today, Russian is only studied by $3 \%$ of EU students, but this varies greatly from one country to another. As was the case in many nation-states in Europe, the language of the numerically dominant group became the official language. Minorities and immigrants had to adapt or leave. The countries where Russian is most studied nowadays are 
those with large population of ethnic Russians: $66 \%$ of Estonian students, $57 \%$ of Latvian students and $33 \%$ of Lithuanian students chose Russian as a foreign language (Eurostat, 2016).

Russia had to face an entirely different challenge: recreating a national identity. The task was difficult because throughout three generations, the Soviet culture had profoundly replaced the Russian one (Gottlieb, 1994). The past 25 years have seen significant hesitance toward building a cultural identity in Russia, unlike many of its neighbours, which either re-established their traditions (middle Asia) or decided to join a community of countries (EU). In Russia, the pendulum of culture swung widely from East to West. Whilst the 1990s are remembered bitterly by many Russians because of harsh material conditions for the population, this post-Imperial hangover was also a rich period of cooperation with other countries such as the United States (International Space Station, nuclear weapons eradication program, support of scholars' trips to the USA, etc) and Europe (TACIS programme, creation of Erasmus Mundus, opening of a Russian representative office at NATO's HQs, etc). Russia was invited to join the G7 (hence becoming the G8 - Group of 8) in 1997, although the GDP of the country was very distant from its counterparts. Whilst the lowest of the seven, Italy, had in 1997 a GDP per capita of $\$ 29,000$, Russia's at that time was only $\$ 3,500$, almost 10 times less. The 1900 s under the leadership of a then Western-friendly V. Putin (see his early interviews) saw a return of Russian culture; people slowly became proud to be Russian again. The economic development strategy based on exporting raw materials (mostly oil and natural gas) to Europe paid off when the price of those commodities rose. Russia was suddenly rich, and its soul-searching was also bearing fruit. A new doctrine emerged, based on the remains of Russia's history, from Tsarist times to the Soviet era.

\section{A New Tsar?}

The political system in Russia is a presidential one and the bicameral parliament bears in reality neither power nor autonomy. The president handpicks the members of Government and loyalty to him is far more needed than political backing or technical competence. However, many saw the re-election of Vladimir Putin in 2012 as a major shift in the direction the country would then follow (Favret, 2012). It is safe to label this shift as the emergence of a new doctrine (Zevelev, 2014). Convergent signs pointed at a coming change of direction: the military conflict in South Ossetia with Georgia in 2008, the resignation in 2011 of the liberal Minister of Finance Alexey Kudrin and the arrest of political activists Pussy Riot (Gessen, 2014). Key political players of the country, first of all, the president, would now display a more conservative, inner-centred and assertive behaviour (Kolesnikov, 2015). The absence of a valid political alternative to V. Putin and the party 'United Russia' and also an increasing reduction of media freedom (RSF, 2016) allowed this new approach to become mainstream not only amongst politicians but also amongst the media and the cultural world. Often, the members of those circles are the same, with a good number of mediatised artists now members of the near-monopolistic party 'United Russia' (Reuter, 2009).

Rather than the political details of this new doctrine, our interest lies in the vision of the role of Russia in its 'near abroad'. It is revealing that the Russian authorities have repeatedly proposed to solve the Ukrainian crisis with representatives from the United States, European Union and Russia itself. The spirit of the Teheran conference in 1943, ahead of the famous Yalta conference, appears to be alive in the Russian Ministry of Foreign Affairs. Russia is now insisting on keeping control on its zone of influence and is communicating that the country is ready to negotiate a new map of the region (Mäkinen, 2016). Whilst the United States officially kept a low profile, it is only natural to observe the European Union as the main opponent of this vision and the European extremist parties as the main supporters. To no surprise, Russia got cosy with their supporters recently, organising conferences with representatives of those political parties and even providing financial support to some of them such as France's Front National (Turchi, 2014. Mestre, Monnot, 2015).

One way to ease the relations between Russia and the 'West' (e.g. the EU, the United States and Japan) would be for the latter to recognise the emergence of the new Russian Empire. Western countries could likely easily level their relationship with Russia by simply accepting the concept of zone of influence in the backyard of Russia. The recognition of Russia's essential role in a multi-polar world is the unfettered goal of many advisors and insiders of the Kremlin (Lavrov, 2008). Such return 
to an Imperial paradigm presents undeniable benefits not only to Russia but also to other countries. The creation of a new buffer zone around the country composed of neutral countries such as Finland, Georgia or Ukraine would ease tensions, providing a cordon between North Atlantic Treaty Organisation (NATO) countries and Russian lands (Mearsheimer, 2014). Russia's assertive stance would ensure that local minorities in multicultural countries such as Ukraine and Moldova, in particular the Russian speakers, would be protected from persecution (Allison, 2014). A new world order with the 'Russian World' as a key player is seen by many as a welcome path to stability (Makarychev, 2014).

Russia has been actively following this path throughout the past decade. The country itself has transformed remarkably in the past 10 years. Not only has the standard of living risen but the structure of the State has also become closer to its Imperial past than to regular Western nation-states. The country's power has become more centralised than before, with regional governors and even the Federal Duma becoming rubber stamps of Kremlin decisions (Demchenko, Golosov, 2016). The annual television speech by Vladimir Putin (he continued the tradition when Prime minister) has become the sole political programme of the government. Courts are notoriously linked to the administrative power and corruption remains as problematic as it has ever been (Rochlitz, 2014). Minorities are legally protected, and various religions enjoy the title of being 'recognised by the State'. Some republics, such as Chechnya or Tatarstan, are now managed very locally, with a strong degree of autonomy from Moscow as long as the loyalty of their leaders is unquestioned (Zabyelina, 2013). Russia has even enlarged its realm by signing military agreements with controversially independent regions such as South Ossetia and Abkhazia, a move very much mirroring the Protectorate status of the 19th and early 20th centuries (Asmus, 2010). Finally, Moscow has been active in the annexation of Crimea, a peninsula where the Russian Black Sea Fleet is located; the region is populated by a majority of Russian speakers but has been an administrative autonomous region of Ukraine since 1954 (Teper, 2016).

Amongst the countries of 'near abroad', Russia has used all of its might to create a feeling of existentialist threats to Russian speakers outside of Russia. This effect is feeding the construction of a much-needed identity. With the use of a powerful state-controlled and well-financed media empire that includes Russia Today (RT) and Sputnik International, the vision of the Kremlin has now been heard throughout the world much more loudly than before (Nimmo, 2016). The country has multiplied the bilateral agreements with middle Asian former USSR republics, and its army is now open to citizens of CIS countries. Russia still has not met its recruiting needs, however, and less than 400 foreigners joined the Russian armed forces during the past 10 years (Stratfor, 2015). Even though, in a few years, the Russian armed forces might count on Kirghiz or Uzbek legions, much like how the tsar could always expect fidelity from the Don Cossacks (Gressel, 2015). All of these processes were carefully engineered, and the result clearly resembles an embryo of an Empire (Saccarelli, Varadarajan, 2015).

\section{Reality Principle}

However, we are in the second decade of the 21 st century and most countries, at least in Europe, believe the time of Empires is gone. The countries that could belong to a buffer zone between Russia and the European Union are now independent, with vigorous democratic institutions. Most opt to remain outside of Russian protection when given the option. Estonia, Latvia and Lithuania - countries that used to be integral members of the USSR - are now active members of the NATO, a military organisation; the European Union, a free-trade political union; the Euro-Zone, a monetary union and the Schengen area, a border-free territory of 25 countries. Other former Warsaw Pact members such as Poland, the Czech republic, Slovakia, Hungary, Romania and Bulgaria all joined the European Union and NATO (Dumetz, Gáboríková, 2016). Serbia and Montenegro, two countries with many historical, religious and military links to Russia are now officially candidates to join the European Union.

Creating much havoc and despite Moscow's wrath, the new Ukrainian government signed the Eastern Partnership, a European Union association and free trade agreement, in June 2014, leading the way to further economic integration between the 42M Slavic country and the economic bloc (Park, 2014). 
Moldova, Georgia and Azerbaijan, three former USSR republics, completed talks and signed this agreement laying the path to stronger cooperation with the 28 members of the European Union (Knott, 2013).

A few other countries, however, decided to keep a close relationship with Russia. Belarus has pulledout of the Eastern Partnership discussion in 2011 in order to deepen its already strong cooperation with Russia (Bosse, 2013). With determination, Russia has created the Eurasian Economic Union with three former USSR countries (Belarus, Kazakhstan and Armenia), but none of them are openly enthusiastic about it and the union is mostly symbolic even now, with customs controls still active at the borders (Tarr, 2015). Countries such as Kyrgyzstan or Uzbekistan, although very dependent on Russia, are hesitant in joining (Peyrouse, 2015. Schmidt, 2014).

Russia today has in appearance many of the artefacts of an Empire but lacks essential features to claim such title, starting with the recognition from the rest of the world (Babones, 2015). The suspension of Russia from the G8 following the Crimean annexation was a strong symbolic sign of the denial of other world powers to acknowledge the country to be part of this elite (Debaere, 2015). Since the fall of the USSR, the country also lacks an exportable ideology such as communism or simply an attractive political programme such as the European Union often associated with a prosperous union of democratic nations living in peace.

The economic aspect is also failing Russia to pretend to the qualification of an Empire. The fundamental data of Russia do not indicate a prosperous country; the Human Development index is \#57 (neighbouring Libya), the GDP per capita is similar to Croatia and the male life expectancy ranks $\# 122$ at 63 y.o., 20 years lower than countries such as Japan, the United States or Germany. In comparison, all the Central and Eastern European countries that joined the European Union enjoyed a steady economic and life expectancy increase over the past 20 years (Glenn, 2015). Unlike former empires such as France or Great Britain, Russia in the 21 st century would be unable to access riches found in colonies, the countries in the 'near abroad' being mostly underdeveloped with few resources useful to Moscow. Thus, the country is forced to drain its own resources to finance its status (Karatnycky, Motyl, 2015). The current expansionist attempt of the Russian leadership and its consequences have direct impact on the well-being of the population (Mironov, 2015). The devaluation of the Russian ruble, the embargo against fresh produces from Europe or the travel restrictions imposed by the Kremlin could lead to social and political unrest amongst the Russian middle class (Dreger et Al., 2016). Russia will soon have to make painful choices: the continuity - at any cost - of its ambitions, or the return to more humble objectives.

\section{Conclusion}

Whilst the constitutive theory confirms the independence of a State only through the recognition of other countries, it is hard to imagine a country unilaterally declaring itself an Empire nowadays (Kumar, 2013). The European Union is a new model of cooperation between nation-states bears some resemblance with an Empire. Being democratic and based upon voluntary membership, the 28member strong organisation, however, does not have many prerogatives in sovereign functions such as taxation or defence. The position of Russia is different. Without any doubt, Russia would wriggle if other nations were to consider it an Empire again. However, the means are missing to such hypothesis. With a limited number of allies in its reach, a lack of political rationale to attract foreign population and a weak economic leverage, the country enjoys a regional influence that is short of Imperial might. Empires strive when they mingle with fellow Empires and do not cooperate well with mere independent countries.

To find stability and prosperity, perhaps Russia should choose a national identity that does not necessarily involve its neighbours but instead concentrates on its own characteristics. In its quest to readmission into the councils of major powers, Russia blinded itself in the belief in an anachronistic status, that of an Empire. It is time for Russia to say farewell to its illusions of an Imperial realm and accept becoming a country comfortable within its own borders. 


\section{References}

Asmus, R. (2010). A little war that shook the world: Georgia, Russia, and the future of the West. Macmillan.

Babones, Salvatore. (2015) "Russia's Eastern Exposure." Foreign Affairs.

BBC, June 25, 2016 «UK votes to LEAVE the EU ». The Referendum took place on June 23, 2016. The vote « Leave » won with $51,90 \%$ of the suffrage. Available from Internet:

http://www.bbc.com/news/politics/eu_referendum/results

Bosse, G., Noutcheva, G., Pomorska, K., (2013). Values versus Security? Assessing the EU's Pragmatic Engagement with Belarus in the Eastern Partnership Policy. The European Union and Its Neighbours: Values versus Security in European Foreign Policy, 173-194.

Carrrère d'Encausse, Hélène, (1992), Victorieuse Russie, Fayard.

Conte, A. (1992). L'épopée coloniale de la France, Plon.

Debaere, P. (2015). The European Union and the Gx System. In EU Coordination in International Institutions: Policy and Process in Gx Forums (pp. 10-19). Palgrave Macmillan UK.

Demchenko, O., \& Golosov, G. V. (2016). Federalism, gubernatorial power and the incorporation of subnational authoritarianism in Russia: A theory-testing empirical inquiry. Acta Politica, 51(1), 61-79.

Dreger, C., Kholodilin, K. A., Ulbricht, D., \& Fidrmuc, J. (2016). Between the hammer and the anvil: The impact of economic sanctions and oil prices on Russia's ruble. Journal of Comparative Economics, 44(2), 295308.

Dumetz, J. , Gáboríková, E., (2016), The Czech and Slovak Republics: A Cross-Cultural Comparison, CrossCultural Business Conference Proceedings 2016

Dumetz, J. in Crane, R. (Ed.). (2014). Building Bridges Among the BRICs. Palgrave Macmillan.

Eurostat, Foreign language learning statistics, Jan. 2016. Available from Internet:

Fabry, P. (2015). Histoire du siècle à venir : Où va le monde selon les cycles de civilisation?, JC Godefroy Editions

Favret, R. (2012). Back to the bad old days: President Putin's hold on free speech in the Russian Federation. Rich. J. Global L. \& Bus., 12, 299.

Front National, Foreign Affairs program (retrieved June 2016). Available from Internet: http://www.frontnational.com/le-projet-de-marine-le-pen/politique-etrangere/notre-politique-etrangere/

Gessen, M. (2014). Words will break cement: The passion of Pussy Riot. Penguin.

Glenn, J. K. (2015). The Economic Opportunities of European Union Enlargement. Economic and Political Contention in Comparative Perspective, 114.

Gottlieb, Gidon. (1994) "Nations Without States." Foreign Affairs. Volume 73, Number 3

Gressel, G. (2015). Russia's quiet military revolution, and what it means for Europe. Policy Brief, ECFR, $n^{\circ} 143$, 4.

Harari, Yuval Noah; Vintage (2014). Sapiens: A Brief History of Humankind.

http://ec.europa.eu/eurostat/statistics-explained/index.php/Foreign_language_learning_statistics

Karatnycky, A., \& Motyl, A. J. (2015). How Putin's Ukrainian Dream Turned Into a Nightmare'. Foreign Policy, vol. 20.

Kerr, P. (1922). From Empire to Commonwealth. Foreign Affairs, 2(2), 83-98.

Knott, E. (2013). Moldova is at the crossroads between Russia and the EU ahead of the Eastern Partnership summit in Vilnius. LSE European Politics and Policy (EUROPP).

Kolesnikov, A. (2015). Russian Ideology After Crimea. Carnegie Moscow Center Paper, September, $22,2015$.

Kumar, K. (2013). Empires and Nations: Convergence or Divergence?, eprints.sifp.it

Langer, William L., (1962), "Farewell to Empire." Foreign Affairs. Vol. 41, Number 1

Lavrov, S. (2008). Russia and the World in the 21st Century. Russia in Global Affairs, 6(3), 8-18. 
Makarychev, A. (2014). Russia and the EU in a Multipolar World: Discourses, Identities, Norms (Vol. 127). ibidem-Verlag/ibidem Press.

Mäkinen, S. (2016). Russia-a leading or a fading power? Students' geopolitical meta-narratives on Russia's role in the post-Soviet space. Nationalities Papers, 44(1), 92-113.

Marrus, M. R. (1985). The unwanted: European refugees in the twentieth century, New York, New York/Oxford, England, Oxford University Press, 1985. xii,

Mearsheimer, J. J. (2014). Why the Ukraine crisis is the West's fault: The liberal delusions that provoked Putin. Foreign Affairs, 93, 77.

Mestre, A., \& Monnot, C. (2015). Chapitre 2/Les réseaux du Front National. In Les faux-semblants du Front national (pp. 51-76). Presses de Sciences Po (PFNSP).

Mironov, V. (2015). Russian devaluation in 2014-2015: Falling into the abyss or a window of opportunity?. Russian Journal of Economics, 1(3), 217-239.

Park, J. (2014). The European Union's Eastern Partnership. Council on Foreign Relations.

Pavlenko, Aneta, (2014), The bilingual mind, Cambridge University Press,

Peyrouse, S. (2015). Kyrgyzstan's Membership in the Eurasian Economic Union: A Marriage of Convenience? Russian Analytical Digest, 165, 10.

Redlich, J. (1929). The End of the House of Austria. Foreign Affairs, 8(1), 598.

Reporters Sans Frontières, Press freedom ranking in 2016 (Russia is \#148). Available from Internet: https://rsf.org/fr/ranking_table

Reuter, O. J., \& Remington, T. F. (2009). Dominant party regimes and the commitment problem the case of united russia. Comparative Political Studies, 42(4), 501-526.

Rochlitz, M. (2014). Corporate Raiding and the Role of the State in Russia. Post-Soviet Affairs, 30(2-3), 89-114.

Saccarelli, E., \& Varadarajan, L. (2015). Imperialism past and present. Oxford University Press, USA.

Schmidt, Simon (2014). "Uzbekistan prefers regime security over economic integration", Open Democracy. (https://www.opendemocracy.net/od-russia/simon-schmidt/uzbekistan-prefers-regime-security-over-economicintegration)

Shapovalova, N., \& Burlyuk, O. (2016). The Situation of National Minorities in Crimea Following its Annexation by Russia. European Parliament Study-Committee on Human Rights.

Stratfor (2015) How Foreigners Can Help the Russian Military (https://www.stratfor.com/analysis/howforeigners-can-help-russian-military)

Tarr, D. G. (2015). The Eurasian Economic Union among Russia, Belarus, Kazakhstan, Armenia and the Kyrgyz Republic: Can it succeed where its predecessor failed?. Belarus, Kazakhstan, Armenia and the Kyrgyz Republic: Can it succeed where its predecessor failed.

Teper, Y. (2016). Official Russian identity discourse in light of the annexation of Crimea: national or imperial?. Post-Soviet Affairs, 32(4), 378-396.

Turchi, M. (2014). Le Front national décroche les millions russes. Mediapart. fr, 22.

World Bank life expectancy statistics at University of Sherbrooke, Canada. Last retrieved on 28/06/2016.

Available from Internet:

http://perspective.usherbrooke.ca/bilan/servlet/BMTendanceStatPays? codeTheme $=3 \& \operatorname{codeStat}=$ SP.DYN.LE00.I $\mathrm{N} \&$ codePays $=\mathrm{CZE} \&$ optionsPeriodes $=$ Aucune $\& \operatorname{codeTheme} 2=3 \& \operatorname{codeStat} 2=$ SP.DYN.LE00.IN\&codePays $2=\mathrm{RU}$ S\&optionsDetPeriodes $=$ avecNomP

Zabyelina, Y. G. (2013). 'Buying Peace' in Chechnya: Challenges of Post-Conflict Reconstruction in The Public Sector. Journal of Peacebuilding \& Development, 8(3), 37-49.

Zevelev, I. (2014). The Russian world boundaries. Russia in Global Affairs, 2. 